\title{
ADIPOR1 wt Allele
}

National Cancer Institute

\section{Source}

National Cancer Institute. ADIPOR1 wt Allele. NCI Thesaurus. Code C103974.

Human ADIPOR1 wild-type allele is located in the vicinity of $1 \mathrm{q} 32.1$ and is approximately $18 \mathrm{~kb}$ in leng th. This allele, which encodes adiponectin receptor protein 1, plays a role in adiponectin-mediated signaling. 